\title{
SPC-2734 Chromalox Oil Heater System Procurement Specification
}

\author{
Terry James Morton
}

November 2019

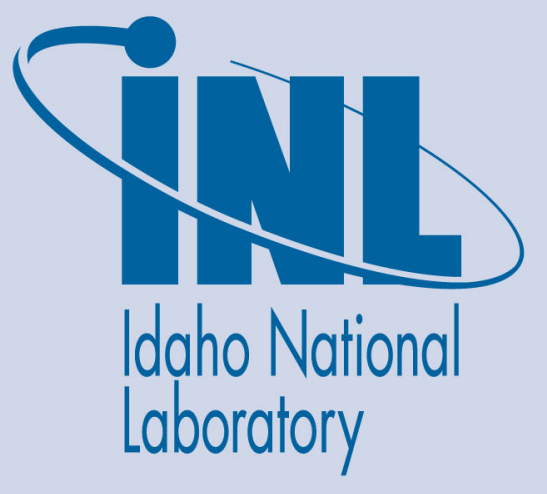

The INL is a U.S. Department of Energy National Laboratory operated by Battelle Energy Alliance 


\title{
SPC-2734 Chromalox Oil Heater System Procurement Specification
}

\author{
Terry James Morton
}

November 2019

Idaho National Laboratory Idaho Falls, Idaho 83415

http://www.inl.gov

Prepared for the

U.S. Department of Energy

Under DOE Idaho Operations Office

Contract DE-AC07-05ID14517 


\section{Specification}

\section{Chromalox Oil Heater System Procurement Specification}

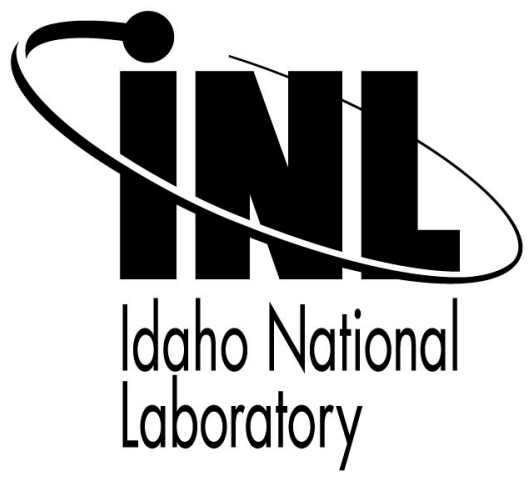

The INL is a U.S. Department of Energy National Laboratory operated by Battelle Energy Alliance. 


\begin{tabular}{l|lll|}
$\begin{array}{c}\text { CHROMALOX OIL HEATER SYSTEM } \\
\text { PROCUREMENT SPECIFICATION }\end{array}$ & $\begin{array}{lll}\text { Revision: } \\
\text { Effective Date: }\end{array}$ & $\begin{array}{l}\text { 11/15/2019 } \\
\text { Page: } 1 \text { of } 6\end{array}$ \\
\hline
\end{tabular}
CONTENTS

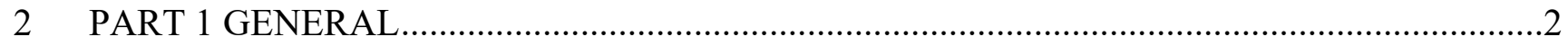

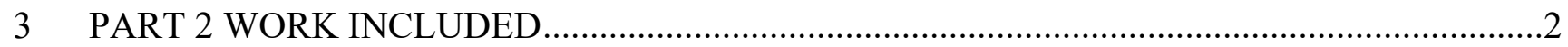

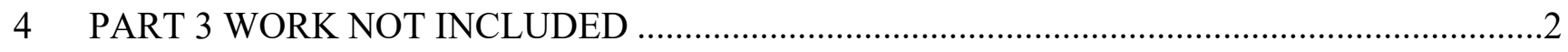

5 PART 4 APPLICABLE CODES, PROCEDURES AND REFERENCES .................................2

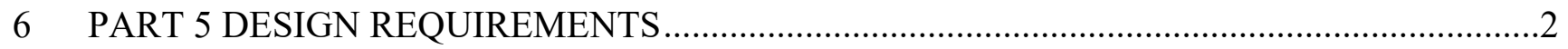

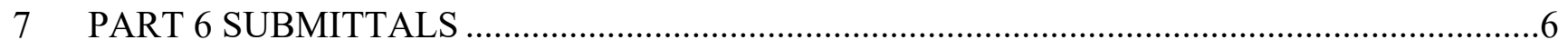

8 PART 7 DELIVERY, STORAGE, AND HANDLING ................................................... 


\begin{tabular}{|c|c|}
\hline $\begin{array}{l}\text { CHROMALOX OIL HEATER SYSTEM } \\
\text { PROCUREMENT SPECIFICATION }\end{array}$ & \begin{tabular}{ll|} 
Identifier: & SPC-2734 \\
Revision: & 0 \\
Effective Date: & $11 / 15 / 2019$
\end{tabular} \\
\hline
\end{tabular}

PART 1 GENERAL

A thermal energy delivery system (TEDS) is being constructed within the dynamic energy transport and integration laboratory (DETAIL) facility to test heat transfer components, distribution systems, instruments, and controls that can be monitored and controlled for hybrid generation of electrical power and/or non-electrical products. TEDS is designed to operate as a part of an integrated system or independently to demonstrate component operations, to develop and validate thermal energy transport models and control systems, and to study thermal energy inertia and storage. Within the integrated system, TEDS will be connected to the INL Real Time Digital Simulator (RTDS) test platform to develop and demonstrate monitoring and control systems and to investigate real-time, hardware-in-the-loop response characteristics relative to grid operations.

As the basis of the TEDS, Chromalox (the vendor) has been chosen to design and supply a heater, pump, storage tanks, and pressure vessel due to their experience with industrial-scale heat transfer oil systems.

TEDS will use Therminol 66 as the synthetic heat transfer oil. Therminol 66 was chosen over other heat transfer oils such as Dowtherm and Drakeol because of its thermal stability, low vapor pressure, and years of industrial experience under a wide range of operating conditions.

\section{PART 2 WORK INCLUDED}

The vendor shall design, fabricate, and supply the following equipment:

A. Hot oil heater system with hot oil pump

B. Thermocline tank (ASME pressure vessel)

C. Expansion tank (ASME pressure vessel)

D. Two unpressurized oil storage tanks

E. Oil heater and pump package controls with interface

\section{PART 3 WORK NOT INCLUDED}

The vendor shall not be responsible for hardware and labor for fixing and mounting of supplied equipment to experiment skid, power and control wiring to facility or process control cabinet, cabling and glands, and local fees/taxes/import duties.

\section{PART 4 APPLICABLE CODES, PROCEDURES AND REFERENCES}

A. ASME Boiler and Pressure Vessel Code Section VIII - Pressure Vessels

B. ASME B31.3 - Process Piping

C. NEMA MG 1 - Motors and Generators; National Electrical Manufacturers Association; 2003

D. NFPA 70 - National Electrical Code; National Fire Protection Association; 2017

E. UL-508A - Standard for Industrial Control Panels

\section{PART 5 DESIGN REQUIREMENTS}

A. System Design Conditions:

1. Pressure

2. Temperature
100 psig $(690 \mathrm{kPa})$

$340^{\circ} \mathrm{C}\left(644^{\circ} \mathrm{F}\right)$ 


\begin{tabular}{l|lll|}
$\begin{array}{l}\text { CHROMALOX OIL HEATER SYSTEM } \\
\text { PROCUREMENT SPECIFICATION }\end{array}$ & $\begin{array}{l}\text { Revififier: } \\
\text { Effective Date: }\end{array}$ & $\begin{array}{l}\text { SPC-2734 } \\
\text { PRI15/2019 }\end{array}$ & Page: 3 of 6 \\
\hline
\end{tabular}

B. System Operating Conditions:

1. Maximum Oil Temperature $325^{\circ} \mathrm{C}\left(617^{\circ} \mathrm{F}\right)$

2. Nominal Hot Oil Supply Temperature $325^{\circ} \mathrm{C}\left(617^{\circ} \mathrm{F}\right)$

3. Nominal Cold Oil Return Temperature $225^{\circ} \mathrm{C}\left(437^{\circ} \mathrm{F}\right)$

4. Nominal Pressure

5. Nominal Mass Flow Rate

0.8 to $1.62 \mathrm{~kg} / \mathrm{s}(1.76$ to $3.57 \mathrm{lbm} / \mathrm{s})$

C. Component Specific Requirements:

1. MOS-650-200P-E182STPDSRGVFCDBHWSGDTPCAEXX (hot oil heater system with main hot oil pump)

- $200 \mathrm{~kW}$

- $480 \mathrm{~V} / 3 \mathrm{PH} / 60 \mathrm{~Hz}$

- ASME Section VIII certified - MAWP: 100 psig@650 ${ }^{\circ} \mathrm{F}$

- 33 gpm@75,

- 5 hp inverter duty motor with VFD

- Analog suction pressure gauge

- Digital overtemperature protection

- Pump housing nozzle loading

\begin{tabular}{|c|c|c|c|c|c|c|}
\hline Nozzle & Fx (lb) & Fy (lb) & Fz (lb) & Mx (ft-lb) & My (ft-lb) & Mz (ft-lb) \\
\hline MOS Pump West Outlet (PT=2010) & 197 & 273 & 105 & 110 & 105 & 329 \\
\hline MOS Pump North Outlet (PT=4080) & 172 & 393 & 93 & 30 & 85 & 184 \\
\hline
\end{tabular}

8

(1)

- Type K thermocouple overheat/no flow safety

- Type J thermocouple temperature control

- Heater vessel nozzles shall be analyzed to accommodate the following loading

\begin{tabular}{|c|c|c|c|c|c|c|}
\hline Nozzle & Fx (lb) & Fy (lb) & Fz (lb) & Mx (ft-lb) & My (ft-lb) & Mz (ft-lb) \\
\hline MOS Heater Bottom (PT=3870) & 517 & 222 & 176 & 196 & 147 & 450 \\
\hline MOS Heater Top (PT=460) & 394 & 73 & 261 & 561 & 160 & 864 \\
\hline
\end{tabular}

- Process control panel with $100 \%$ SCR heater control and disconnect

- Strainer

- Inlet and outlet gate valves

- Dedicated fill line and drain/bleed valves

- See included drawing package for system layout and process inlet and outlet nozzle general locations

- Additional nozzles shall be included for accessories such as pressure and temperature sensor weld-o-lets - these nozzles shall be connected in the field

- See included drawing package and system specification for painting requirements

2. Thermocline tank

- ASME Section VIII certified - MAWP: 100 psig @ 650 F

- See included drawing package for nozzle locations and sizes

- See included drawing package and system specification for painting requirements

- Thermocline tank nozzles shall be analyzed to accommodate the following loading 


\begin{tabular}{l|lll|}
$\begin{array}{l}\text { CHROMALOX OIL HEATER SYSTEM } \\
\text { PROCUREMENT SPECIFICATION }\end{array}$ & $\begin{array}{l}\text { Revififier: } \\
\text { Effective Date: }\end{array}$ & $\begin{array}{l}\text { SPC-2734 } \\
\text { PRI5/2019 }\end{array}$ & Page: 4 of 6 \\
\hline
\end{tabular}

\begin{tabular}{|c|c|c|c|c|c|c|}
\hline Nozzle & Fx (lb) & Fy (lb) & Fz (lb) & Mx (ft-lb) & My (ft-lb) & Mz (ft-lb) \\
\hline Thermocline Tank Top (PT=110) & 53 & 54 & 425 & 178 & 195 & 64 \\
\hline Thermocline Tank Bottom (PT=3440) & 580 & 244 & 364 & 472 & 225 & 643 \\
\hline
\end{tabular}

- A flow distribution baffle and support plate with a $40 \%$ void area shall be fabricated to sit in the bottom of the tank on legs (see Figure 1 and Figure 2) per face to face communications with the vendor

- Slots shall be 0.8 inches in width

- A perforated carbon steel sheet with $1 / 16$ " round holes on $3 / 32$ " staggered centers, of at least 20 gauge thickness, shall be tack welded to the flow distribution baffle in a sufficient number of places to prevent any movement of the perforated sheet

- Baffle and perforated sheet to support $4,800 \mathrm{~kg}$ (10,582 pounds) of $1 / 8$ " alumina beads

- A similar distribution baffle, with like perforated carbon steel sheet, and spring loaded legs shall be fabricated to sit atop the beads and compress them when the vessel top is installed.

- The baffles and supports shall be fabricated of carbon steel of a specification similar to that of the vessels to ensure like thermal expansion characteristics.

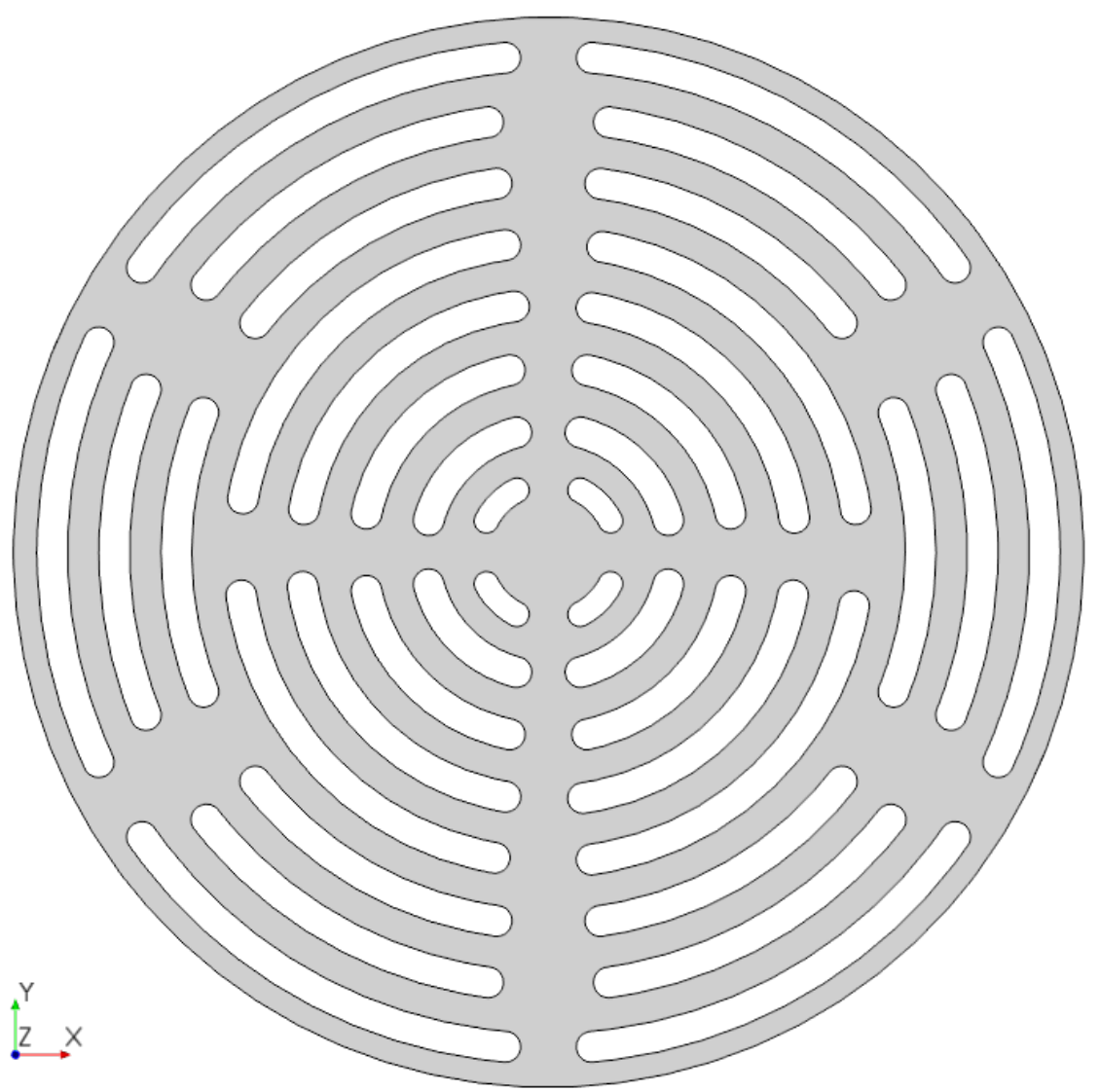




\begin{tabular}{l|lll|} 
CHROMALOX OIL HEATER SYSTEM & Identifier: & SPC-2734 & \\
PROCUREMENT SPECIFICATION & Revision: & 0 & \\
& Effective Date: & $11 / 15 / 2019$ & Page: 5 of 6 \\
\hline
\end{tabular}

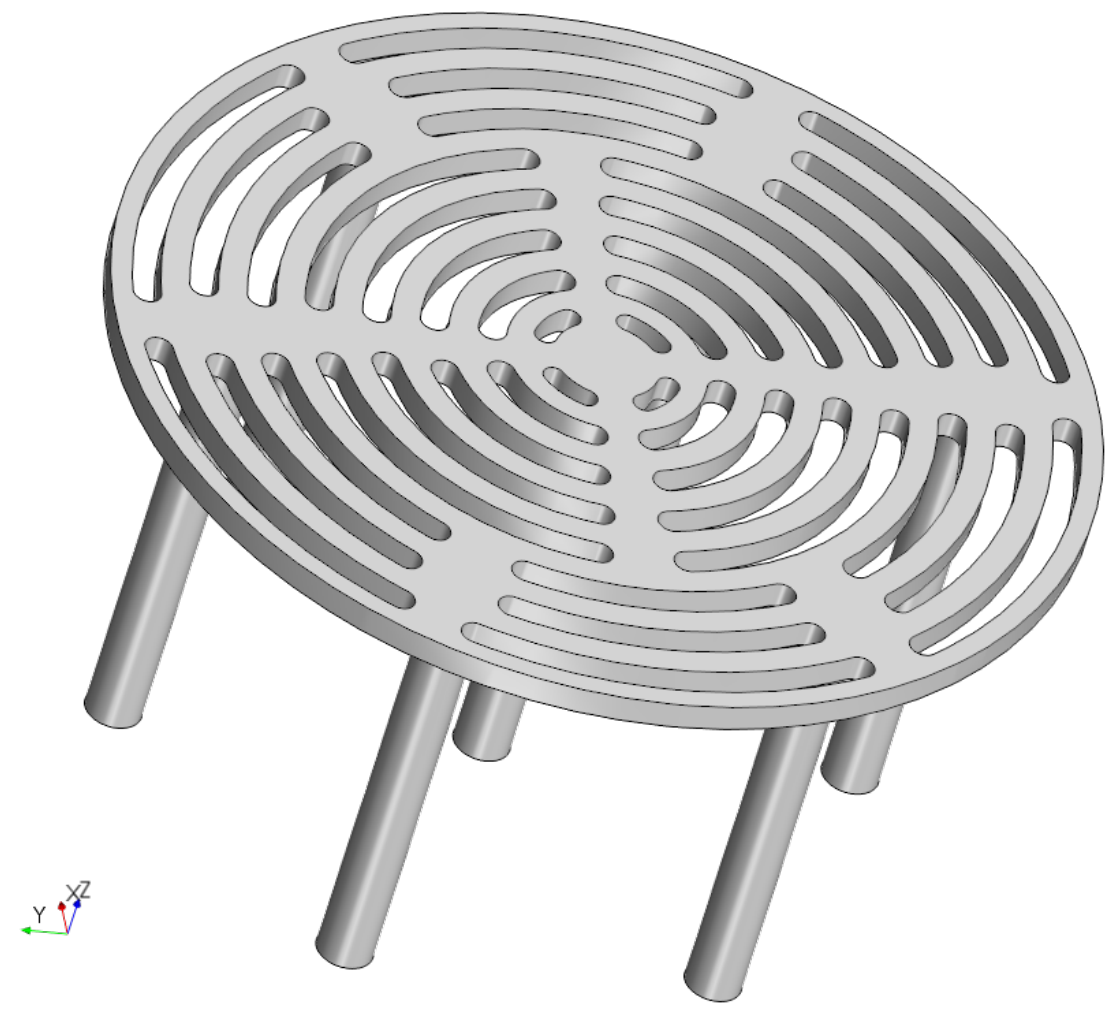

Figure 2 Conceptual Support and Baffle Isometric View

3. 300-gallon expansion tank

- ASME Section VIII certified - MAWP: 100 psig @650 ${ }^{\circ} \mathrm{F}$

- Tank shall be equipped with nitrogen regulator and back-pressure regulator (shipped loose), magnetic indicating liquid level transmitter, and a port for a safety relief valve (relief valve by others)

- See included drawing package for process inlet/outlet nozzle locations and sizes

- Additional nozzles, e.g., level indication or thermowell nozzles, shall be connected by field routed piping

- See included drawing package and system specification for painting requirements

- Expansion tank nozzles shall be analyzed to accommodate the following loading

\begin{tabular}{|c|c|c|c|c|c|c|}
\hline Nozzle & Fx (lb) & Fy (lb) & Fz (lb) & Mx (ft-lb) & My (ft-lb) & Mz (ft-lb) \\
\hline Expansion Tank West Outlet (PT=2410) & 21 & 40 & 24 & 86 & 51 & 9 \\
\hline Expansion Tank East Outlet (PT=2950) & 22 & 43 & 27 & 100 & 62 & 2 \\
\hline
\end{tabular}

4. 500-gallon, unpressurized storage tanks

- See included drawing package for system layout and process inlet and outlet nozzle general locations and sizes

- Additional nozzles, e.g., level indication or thermowell nozzles, shall be connected by field routed piping

- See included drawing package and system specification for painting requirements

- Thermocline tank nozzles shall be analyzed to accommodate the following loading 
Idaho National Laboratory

\begin{tabular}{|c|c|c|c|}
\hline $\begin{array}{l}\text { CHROMALOX OIL HEATER SYSTEM } \\
\text { PROCUREMENT SPECIFICATION }\end{array}$ & $\begin{array}{l}\text { Identifier: } \\
\text { Revision: } \\
\text { Effective Date: }\end{array}$ & $\begin{array}{l}\text { SPC-2734 } \\
0 \\
11 / 15 / 2019\end{array}$ & Page: 6 of 6 \\
\hline
\end{tabular}

\begin{tabular}{|c|c|c|c|c|c|c|}
\hline Nozzle & Fx (lb) & Fy (lb) & Fz (lb) & Mx (ft-lb) & My (ft-lb) & Mz (ft-lb) \\
\hline North Storage Tank (PT=3050) & 218 & 191 & 141 & 106 & 31 & 190 \\
\hline South Storage Tank (PT=3150) & 247 & 83 & 26 & 30 & 5 & 207 \\
\hline
\end{tabular}

D. Electrical Requirements

1. All electrical components and assemblies (motors, heaters, wiring, etc) shall be NRTL listed and labeled

2. All electrical components and assemblies shall be installed in accordance with the applicable requirements of the NEC (NFPA 70-2017)

3. Control panel shall be listed and labeled to UL 508A standards

E. Controls

1. Control panel shall be equipped with Modbus TCP/Ethernet and shall allow monitoring of process variables, hot oil temperature setpoint adjustment, and alarm monitoring from a National Instruments LabView program (by others)

2. Start, stop, and frequency adjustment shall be available from National Instruments LabView program (by others)

\section{PART 6 SUBMITTALS}

Vendor data, including tank dimension drawings, pump curves, and installation, operation, and maintenance manuals shall be submitted to INL by electronic distribution.

A. Tank dimension drawings submitted for design review prior to tank fabrication

B. Operation \& Maintenance Manual: O\&M Manuals shall be the standard publication issued for the product by the manufacturer submitted upon system delivery

C. ASME Certificate of Accreditation submitted upon system delivery

D. Component drawings submitted upon system delivery

E. Completed U-1A forms for ASME stamped pressure vessels delivered upon system delivery

\section{PART 7 DELIVERY, STORAGE, AND HANDLING}

System component delivery shall be coordinated with installing sub-contractor. Storage and handling shall be in accordance with vendor's instructions. Equipment shall be inspected upon arrival. 